$\begin{array}{llllllllllllllll}M & \mathrm{I} & \mathrm{S} & \mathrm{C} & \mathrm{E} & \mathrm{L} & \mathrm{L} & \mathrm{A} & \mathrm{N} & \mathrm{E} & \mathrm{A}\end{array}$

\title{
Polskie biblioteki i problemy polskiego bibliotekarstwa w niemieckim piśmiennictwie fachowym ${ }^{1}$
}

STreszczenie. Czasopisma bibliotekoznawcze nie odgrywają znaczącej roli w niemieckim bibliotekarstwie, jednak dość wiernie odzwierciedlają najważniejsze zagadnienia współczesnego bibliotekarstwa niemieckiego.

Wybór tematów, jakie pojawiają się w ogólnokrajowych czasopismach fachowych, jest bardzo bogaty i wewnętrznie zróżnicowany: budownictwo i technika biblioteczna, katalogowanie, przetwarzanie danych, automatyzacja, szeroki dostęp do wszechstronnej informacji, a obok tego - przyjazne podejście do użytkowników, wszechstronne zaspokajanie ich potrzeb, kształcenie i doskonalenie umiejętności bibliotekarzy.

Marginalnie i niesystematycznie ukazują się teksty dotyczące problemów współczesnego bibliotekarstwa zagranicznego, nie wyłączając bibliotekarstwa polskiego. Znajdziemy natomiast $\mathrm{w}$ piśmiennictwie niemieckim informacje na temat dziejów polskiej książki i bibliotek, zwłaszcza gdy chodzi o wczesne lata nowożytne. Dla niemieckich germanistów szczególnie interesujące są historyczne księgozbiory niemieckie w Europie Środkowo-Wschodniej.

SŁowA KLUCzowe: Niemcy, piśmiennictwo bibliotekarskie, czasopisma bibliotekarskie, polskie bibliotekarstwo.

Informacji na temat tytułowego zagadnienia szukałem, przeglądając zawartość najważniejszych niemieckich czasopism bibliotekoznawczych o zasięgu ogólnokrajowym, takich jak:

- „Bibliotheksdienst” - ukazujący się od 1967 roku miesięcznik, wydawany przez Niemiecki Instytut Biblioteczny (Deutsche

1 Prezentowany tekst wygłoszony został na zebraniu naukowym w Bibliotece Uniwersyteckiej w Poznaniu (w grudniu 2013 roku). Przedstawia osobiste stanowisko autora, ale ważkość tematu i obszerna bibliografia skłoniły Redakcję do jego opublikowania. 
Bibliotheksinstitut), w którym sygnalizowane są obecnie wszystkie praktyczne zagadnienia bibliotekarskie oraz wszelkiego rodzaju informacje przysyłane $\mathrm{z}$ różnych bibliotek na temat organizowanych przez nie wystaw, konferencji, podejmowanych akcji i inicjatyw. Od roku 2000 pismo wydaje Centralna i Krajowa Biblioteka w Berlinie (Zentral- und Landesbibliothek Berlin), od roku 2013 wspomagana przez Krajowe Centrum Biblioteczne Nadrenii-Palatynatu (Landesbibliothekszentrum Rheinland-Pfalz) w Koblencji.

- "Zeitschrift für Bibliothekswesen und Bibliographie" - pismo wydawane przez Związek Bibliotekarzy Naukowych i Bibliotekarzy Dyplomowanych w Bibliotekach Naukowych. W roku 1991 połączyło się z ukazującym się od 1884 roku i kontynuowanym po roku 1945 w NRD czasopismem "Zentralblatt für Bibliothekswesen". Obecnie jest to najważniejszy tytuł podejmujący problematykę bibliotekoznawczą w Niemczech.

- „Buch und Bibliothek” - ukazuje się od roku 1949 i jest wydawane przez Związek Bibliotekarzy Bibliotek Publicznych, w roku 2001 przekształcony w Zjednoczenie Zawodowe Biblioteka i Informacja (Berufsverband Bildung und Information). W tym samym roku zmieniono tytuł pisma na: „Buch und Bibliothek Forum Bibliothek und Information". Jednocześnie zadecydowano, że od tego roku ukazuje się ono jako magazyn. Dzisiaj jest czasopismem bibliotekarskim o prawdopodobnie najwyższym nakładzie.

- „Bibliothek. Forschung und Praxis” - założone w 1972 roku przez kierownika pierwszej w RFN Katedry Bibliotekoznawstwa na uniwersytecie w Kolonii, Paula Kagebeina. W periodyku problemy stricte bibliotekoznawcze łączy się z zagadnieniami praktycznymi, dotyczącymi funkcjonowania wszystkich rodzajów bibliotek, przy czym uwagą obejmuje się nie tylko biblioteki niemieckie, ale również biblioteki działające w krajach niemieckojęzycznych.

Problematyką nowej, opartej na współczesnych technologiach informacyjnych biblioteki zajmują się interesująco dwa nowe czasopisma: ukazujące się od roku 1981 „ABI-Technik. Zeitschrift für Automation, Bau und Technik im Archiv-, Bibliotheks- und Informationswesen" oraz znacznie późniejsze - „BIT-Online. Zeitschrift für Bibliothek, Information, Technik".

Szczególnie ważne w kontekście moich poszukiwań jest „ABDOS-Mitteilungen der Arbeitsgemeinschaft der Bibliotheken und Dokumentationstellen der Ost, Ostmittel- und Südosteuropaforschung". W roku 2012 Wydawnictwo Otto Sanger zmieniło tytuł na "Bibliothek und Medien”, 
który dziś może wprowadzać czytelnika w błąd². Uprzedzając nieco dalsze uwagi, trzeba stwierdzić, że bibliotekarze polscy bardzo rzadko korzystali z tego, wydawałoby się, naturalnego forum, by poinformować bibliotekarzy niemieckich o aktualnym stanie polskiego bibliotekarstwa i prowadzonych badaniach ${ }^{3}$. Drobne wiadomości na ten temat znaleźć można w publikowanych w tym czasopiśmie materiałach pokonfrencyjnych, będących plonem spotkań organizowanych przez Wspólnotę Roboczą ABDOS4 ${ }^{4}$. Szerszej i bardziej dynamicznie prowadzonej współpracy nie ułatwia fakt, że redakcja "Bibliothek und Medien” jest zdana na dobrowolnie i dość przypadkowo dostarczane teksty.

Dla porządku wymienię jeszcze czasopisma luźniej związane z interesującą mnie problematyka, które ukazują się w poszczególnych landach i zasięgiem raczej poza macierzyste landy nie wykraczają. Są to: „Pro Libris”, wydawane w Nadrenii Północnej-Westfalii, oraz „Bibliotheken Heute", ukazujące się w Nadrenii-Palatynacie. Ponadto funkcjonują jeszcze: „Dialog mit Bibliotheken”, wydawany przez Niemiecką Bibliotekę Narodową we Frankfurcie nad Menem i w Lipsku, czy „Bibliotheks-Magazin", publikowany od roku 2009 przez Bawarską Bibliotekę Państwową i Bibliotekę Państwową / Pruskie Dziedzictwo Kulturowe - dwie najważniejsze biblioteki humanistyczne w Niemczech. Dwa ostatnie periodyki zawierają dużo materiałów promocyjnych i reklamowych.

Wprawdzie czasopisma bibliotekoznawcze nie odgrywają znaczącej roli w Niemczech, dość wiernie jednak odzwierciedlają najważniejsze zagadnienia współczesnego bibliotekarstwa niemieckiego. Analiza roczników poszczególnych czasopism czyniona w dłuższym przedziale czasowym pozwala uchwycić zmieniająca się hierarchię tematów i podejmowanych zadań oraz usytuowanie bibliotek we współczesnym świecie.

Zakres problemów, jakie pojawiają się w ogólnokrajowych czasopismach bibliologicznych, jest bardzo bogaty i wewnętrznie zróżnicowany: budownictwo i technika biblioteczna, katalogowanie, przetwarzanie danych,

2 Zob. spis zawartości 1981-2000, w: W. Kessler, 20 Jahrgänge ABDOS(D)-Mitteilungen 1981-2000 - 30 Jahre ABDOS(D), „Mitteilungen / Arbeitsgemeinschaft der Bibliotheken und Dokumentationsstellen der Ost-, Ostmittel- und Südosteuropaforschung (ABDOS)" 2000, t. 20, nr 4, s. 1-28.

3 Wyjątki stanowią na przykład A. Jazdon, Die Universitätsbibliothek in Poznan. Geschichte-Gegenwart-Probleme, „ABDOS-Mitteilungen” 1992, t. 12, nr 4, s. 4-11; K. Zielnica, Die Universitätsbibliothek Wrocław (Breslau), „ABDOS-Mitteilungen” 1995, t. 15, nr 1, s. 12-14; L. Brzeżycka, Probleme der Erhaltung und Konservierung der Sammlungen der Książnica Cieszyńska, „ABDOS-Mitteilungen” 2004, t. 24, nr 1-2, s. 1-11.

4 Zob. spis zawartości w: W. Kessler, 20 ABDOS-Tagungsbändeund zwei Festschriften. Eine Bibliographie, „ABDOS-Mitteilungen” 2004, t. 24, nr 1-2, s. 14-31. 
automatyzacja, szeroki dostęp do wszechstronnej informacji, a oprócz tego przyjazne podejście do użytkowników, kompleksowe zaspokajanie ich potrzeb, kształcenie i doskonalenie umiejętności bibliotekarzy. W ostatnich latach zdecydowanie zaczęły dominować tematy związane z szeroko rozumianą cyfryzacją bibliotek: komputerowe opracowanie zbiorów, sieć, system, biblioteka cyfrowa - to daleko niepełna lista najważniejzych zagadnień.

Marginalnie natomiast i niesystematycznie pojawiają się teksty dotyczące problemów bibliotekarstwa zagranicznego. Najczęściej dotyczą budownictwa bibliotecznego oraz zmian organizacyjnych. Uwaga autorów skierowana jest jednak przede wszystkim na Europę Zachodnią i Stany Zjednoczone. Dość powiedzieć, że w publikacji z 2008 roku, która jest przeglądem i omówieniem ustaw bibliotecznych obowiązujących w Europie, ani jednym słowem nie wspomniano o państwach Europy Wschodniej.

Czego dowiadują się z tych czasopism niemieckie bibliotekarki i niemieccy bibliotekarze o bibliotekarstwie w Polsce?

Do roku 1980 Polska pozostawała w zachodnioniemieckich czasopismach bibliotekarskich terra incognita. Ówczesny kierownik biblioteki Instytutu im. Herdera w Marburgu, Horst von Chmielewski, stwierdził w roku 1981 we Wprowadzeniu do wyboru aktualnych tekstów na temat sytuacji bibliotek w Polsce, że „informacje o bibliotekarstwie w PRL-u nie pojawiają się nawet $\mathrm{w}$ tekstach o podręcznikowym charakterze" ${ }^{\prime \prime}$. Udało mu się znaleźć tylko jeden artykuł, który bardzo pobieżnie informował o sytuacji bibliotek w Polsce po II wojnie światowej ${ }^{7}$. Gdyby Chmielewski rozszerzył poszukiwania o czasopisma wschodnioniemieckie, to musiałby swój surowy osąd nieco złagodzić. W ukazującym się w Lipsku piśmie „Zentralblatt für Bibliothekswesen" znalazłby stosowne teksty autorów wschodnioniemieckich ${ }^{8}$ i polskich 9 . Dodatkowo w prowadzonej przez

5 B. Schleihagen, Bibliotheksgesetze in Europa - Mittel politischer Steuerung und Gestaltung, "Bibliothek. Forschung und Praxis" 2008, t. 32, nr 1, s. 14-20.

6 H. von Chmielewski, Bibliotheken in Polen. Grundsätzliche und aktuelle Fragen, "Dokumentation Ostmitteleuropa” 1981, nr 5, s. 1 (219), wskazuje na „Osteuropa-Handbuch” Polen, red. W. Markert, Köln-Graz 1959 oraz Polen, wyd. Johann Gottfried Herder-Institut Marburg, München 1976 (Länderberichte Osteuropa 2). O autorze zob. W. Kessler, Horst v. Chmielewski im Ruhestand, „ABDOS-Mitteilungen” 1999, t. 19, nr 1, s. 29-30.

7 K. Hartmann, Archive und Bibliotheken in Polen, „Osteuropa” R. 9, 1959, s. 832-835.

8 P. Prohl, Neubauten wissenschaftlicher Bibliotheken in der Volksrepublik Polen, „Zentralblatt für Bibliothekswesen” 1968, t. 82, nr 10, s. 601-612; E. Kunz, P. Prohl, Neubauten von Hochschulbibliotheken in der Volksrepublik Polen, "Zentralblatt für Bibliothekswesen" 1978, t. 92, nr 3, s. 138-146; P. Prohl, Jerzy Wierzbicki zum 75. Geburtstag, „Zentralblatt für Bibliothekswesen” 1982, t. 96, s. 119-125.

9 R. Ergetowski, Die Universitätsbibliotheken in Polen. Historischer Abriss, "Zentralblatt für Bibliothekswesen" 1975, nr 3, s. 106-107. O autorze (1925-2005) zob. J. Tyl, 
to czasopismo rubryce „Kronika” regularnie ukazywały się wiadomości z Polski, z przerwą w latach 1983-1987.

Na początku lat 80 . XX wieku, kiedy w społeczeństwie zachodnioniemieckim wzrosło zainteresowanie Polską, zaczęły pojawiać się pierwsze publikacje rzetelnie informujące o sytuacji w polskim bibliotekarstwie. Szczególnie interesujący w tym kontekście był artykuł Ryszarda Ergetowskiego zatytułowany Zarys dziejów bibliotek uniwersyteckich $i$ akademickich w Polsce ${ }^{10}$.

Równie ważna była rozprawa znawcy historii książki na Śląsku i profesora bibliologii w Moguncji Gerarda Świerka (swoją pracę doktorską bronił na Uniwersytecie Wrocławskim) zatytułowana Socjalistyczna teoria i praktyka nauki o ksiażce w Europie Wschodniej ${ }^{11}$. W aneksie autor zamieścił krótki przegląd organizacji i struktur bibliotecznych w PRL-u ${ }^{12}$.

Porównywalna z tymi dwoma - jeśliby uwzględnić zawartość informacyjną i faktograficzą rzetelność - jest praca Barbary Bieńkowskiej i Haliny Chamerskiej opublikowana w 1990 roku $^{13}$. W tym samym roku Szkoła Bibliotekarska im. Ericha Weinerta w Lipsku wydała skrypt dla studentów zaocznych, w którym znalazły się wiadomości o bibliotekarstwie w Polsce.

Na początku lat 80 . w niemieckich czasopismach zaczęły się pojawiać wypowiedzi polskich autorów zwięźle informujące o aktualnej sytuacji w polskim bibliotekarstwie i głównych kierunkach prowadzonych badań. Myślę tutaj o Jadwidze Kołodziejskiej ${ }^{14}$ i dyrektorze Biblioteki Narodowej Witoldzie Stankiewiczu, którego referat Główne kierunki rozwoju bibliotekarstwa polskiego wygłoszony na Niemieckim Zjeździe Bibliotekarzy

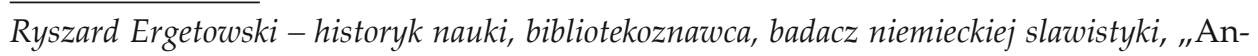
nales Academiae Paedagogicae Cracoviensis” 2007, f. 47 (Studia ad Bibliothecarum Scientiam Pertinentia 5), s. 180-205. K. Kuźmińska, Bemerkungen zum neuen Bildungssystem und zur Ausbildung der Bibliothekare in Polen, "Zentralblatt für Bibliothekswesen" 1979, t. 93, nr 3, s. 97-103; C.Z. Galczyńska, Zur Territorialbibliographie in Polen, „Zentralblatt für Bibliothekswesen” 1988, t. 102, nr 6, s. 252-257.

${ }^{10}$ R. Ergetowski, Universitätsbibliotheken und Bibliotheken der Akademie der Wissenschaften in Polen. Abriss der Geschichte, Frankfurt am Main 1981.

11 A.G. Świerk, Zur sozialistischen Theorie und Praxis des Buchwesens in Osteuropa, Wiesbaden 1981. Por. A. Świerk, Średniowieczna biblioteka klasztoru kanonikow regularnych św. Augustyna w Żaganiu, Wrocław 1965.

12 A.G. Świerk, Zur sozialistischen Theorie..., s. 176-182.

${ }^{13}$ B. Bienkowska, H. Chamerska, Books in Poland. Past and present, Wiesbaden 1990, s. 80-98: Polish Libraries After World War II.

${ }^{14}$ J. Kołodziejska, Bibliothekswissenschaft in Polen, „Bibliothek. Forschung und Praxis" 1981, t. 5, nr 1, s. 66-71. 
w Ratyzbonie wydrukowano w "Zeitschrift für Bibliothekswesen und Bibliographie"15.

Od tamtego czasu bibliotekarze niemieccy coraz częściej uczestniczyli w różnego rodzaju konferencjach naukowych organizowanych przez polskich bibliotekarzy, co w naturalny sposób sprzyjało wzrostowi zainteresowania polskim bibliotekarstwem i bibliotekoznawstem ${ }^{16}$. Niestety nie znajdziemy drukowanych publikacji pokonferencyjnych. Kwerenda w czasopismach pozwala odnotować tylko krótkie informacje z roku 1986, czterostronicowy komunikat Jana Sójki na temat organizacji i zarządzania ${ }^{17}$ oraz, zamieszczony w księdze pamiątkowej dla Jakuba Kaegbeina, szkic Jadwigi Kołodziejskiej o znaczeniu bibliotek dla kultury czytelniczej w Polsce ${ }^{18}$.

Na początku lat 90. bibliotekarze z Biblioteki Uniwersyteckiej w Grazu Franz Koller i Sigrid Reinitzer - opublikowali serię rozpraw przeglądowych na temat bibliotekarstwa w Europie Środkowej, w tym i w Polsce $^{19}$. Z kolei na planowanie nowych budynków bibliotecznych w Polsce w roku 1993 zwrócił uwagę Robert Klaus Jopp ${ }^{20}$.

W roku 2004 w ramach "Bibliothek. Forschung und Praxis” wydano zeszyt tematyczny Biblioteki w nowych krajach Unii Europejskiej, w którym osiem stron poświęcono Polsce: Artur Paszko napisał o znaczeniu bibliotek wojewódzkich, Elżbieta Górska o roli bibliotek publicznych, a Henryk Hollender o aktualnej kondycji bibliotek naukowych ${ }^{21}$.

${ }^{15}$ W. Stankiewicz, Die Hauptrichtungen der Entwicklungen des polnischen Bibliothekswesens, w: Bestände in wissenschaftlichen Bibliotheken. Erschliessung und Erhaltung, 71. Dt. Bibliothekartag in Regensburg vom 9.-13. Juni 1981, red. J. Hering, E. Zwink, Frankfurt am Main 1982 (,Zeitschrift für Bibliothekswesen und Bibliographie”, Sonderheft 34), s. 260-266.

${ }^{16}$ D.D. Rusch, Buch und Bibliothek in der Gesellschaft, „Bibliothek. Forschung und Praxis" 1981, t. 5, nr 1, s. 78-82; H. von Chmielewski, Das polnische Bibliothekswesen, „Bibliothek. Forschung und Praxis” 1981, t. 5, nr 2, s. 187-189.

17 J. Sójka, Organisation und Verwaltung der Bibliotheken von Hochschulen in Polen. Eine Einführung, „Bibliotheksdienst” 1986, t. 20, nr 2, s. 128-130.

${ }^{18}$ J. Kołodziejska, Die Bibliothek als kulturelle Einrichtung. Zur Lesekultur in Polen, w: Buch und Bibliothekswissenschaft im Informationszeitalter. Festschrift Paul Kaegbein zum 65. Geburtstag, München 1990, s. 28-37.

${ }^{19}$ F. Kroller, S. Reinitzer, Das Bibliotheks- und Informationswesen der Republik Polen, „ABI-Technik" 1994, t. 14, nr 1, s. 1-20.

${ }^{20}$ R.K. Jopp, Neue wissenschaftliche Bibliotheken in Polen, "ABI-Technik” 1995, t. 15, nr 3, s. 251-261.

${ }^{21}$ Die Bibliotheken in den neuen EU-Ländern, „Bibliothek. Forschung und Praxis" 2003, t. 27, nr 2; A. Paszko, Die Wojewodschaftsbibliotheken in Polen als regionale 
Od roku 2005 ukazuje się, wydawane w formie elektronicznej przez Instytut Nauki o Bibliotece i Informacji Uniwersytetu im. Humboldta w Berlinie, czaspismo „Libreas - Library”, gdzie opublikowany został zwięzły, utrzymany w bardzo przyjaznym tonie artykuł Stephanie Funk o historii i współczesności polskiego bibliotekarstwa ${ }^{22}$.

W periodyku „Bibliotheken Heute” - wydawanym przez Krajowe Centrum Biblioteczne Nadrenii-Palatynatu - w tomie z roku 2012, zamieszczono krótką notkę na temat kształcenia bibliotekarzy w Polsce i w Czechach. Tekst ten to pokłosie wizyt bibliotekarzy z Kladna i Opola w Koblencji ${ }^{23}$.

Rzadko można znaleźć wiadomości na temat - wydawałoby się - dla niemieckiego odbiorcy szczególnie interesujący. Myślę o historycznych księgozbiorach niemieckich, które znalazły się w Polsce. Najwyraźniej uznano, że informacje na ten temat zawarte w Przewodniku po niemieckich ksiegozbiorach historycznych w Europie są zupełnie wystarczające ${ }^{24}$.

W 2009 roku w elektronicznym piśmie „BIT-online” zamieszczono rzetelny tekst Agaty Dudy i Dietera Kummera o Bibliotece Śląskiej w Katowicach ${ }^{25}$. Jest to tym ważniejsze, że wcześniejszy artykuł na ten temat, autorstwa Zbigniewa Żmigrodzkiego, choć ukazał się w języku niemieckim, nie został w Niemczech dostrzeżony ${ }^{26}$. Na marginesie warto zauważyć, że w ogóle publikacje wydane w Polsce, choć pisane w językach zachodnioeuropejskich, w Niemczech są prawie niezauważane. Być może przesądza o tym źle zorganizowana dystrybucja i promocja.

Na temat dziejów Biblioteki Uniwersyteckiej we Wrocławiu napisano dwie solidne monografie, ale we współczesnych niemieckich czasopismach nie znajdziemy żadnych informacji na temat funkcjonowania tej biblioteki obecnie ${ }^{27}$. Zbiory specjalne wrocławskiej książnicy scharakteryzował

Büchereien, s. 203-204; E. Górska, Öffentliche Bibliotheken in Polen, s. 199-202; H. Hollender, Die wissenschaftliche Bibliothek in Polen, s. 197-199.

22 S. Funk, Östlich der Oder: Polen und sein Bibliothekswesen, „Libreas” 2006, t. 7, http://libreas.eu/ausgabe7/005fun.htm [dostęp: 30.11.2013].

${ }^{23}$ Bibliothekarische Aus- und Fortbildung in der Tschechischen Republik und in Polen (2012), „Bibliotheken Heute” 2012, t. 8, nr 1, s. 7-10.

${ }^{24}$ Handbuch deutscher historischer Buchbestände in Europa. Eine Übersicht über Sammlungen in ausgewählten Bibliotheken, red. B. Fabian, t. 6: Polen, Hildesheim 1999.

${ }^{25}$ A. Duda-Koza, D. Kummer, Die Biblioteka Slaska Katowice. Die älteste und größte polnische Bibliothek in Oberschlesien, „BIT-Online” 2009, t. 12, nr 3, s. 333-337.

${ }^{26}$ Z. Żmigrodski, Die Schlesische Bibliothek zu Kattowitz und ihre bibliographische Tätigkeit, "Joseph-von Eichendorff-Konservatorium” 1999, t. 24, s. 28-38.

27 O. Kape, Die Geschichte der wissenschaftlichen Bibliotheken in Breslau in der Zeit von 1945 bis 1955 unter besonderer Berücksichtigung der Universitätsbibliothek, St. Katha- 
Julian Fercz na konferencji ${ }^{28}$ zorganizowanej przez ABDOS w 1997 roku, a ogólny przegląd dostępności bibliotek i archiwów na Śląsku omówił Andrzej Ładomirski w przygotowanym wspólnie z Ewą Głodowską referacie wygłoszonym na konferencji w roku $1995^{29}$.

Generalnie województwo śląskie jest stosunkowo dobrze prezentowane $\mathrm{w}$ różnego rodzaju materiałach wydawanych przez ABDOS, przede wszystkim za sprawą Zbigniewa Żmigrodzkiego i Zdzisława Gębołysia, którzy bardzo aktywnie uczestniczyli w konferencjach organizowanych przez to stowarzyszenie ${ }^{30}$.

O współczesnych problemach i tendencjach rozwojowych poznańskich bibliotek publicznych informowała Zofia Platkiewicz ${ }^{31}$, a Artur Jazdon napisał o niemieckojęzycznych zasobach Biblioteki Uniwersyteckiej w Poznaniu. Ta ostatnia publikacja dostrzeżona została przede wszystkim w środowisku niemieckich historyków, jako że ukazała się w czasopiśmie historycznym $^{32}$. Władysław Michnal scharakteryzował zasoby Książnicy

rinen 1993; A. Rüffler, Die Stadtbibliothek Breslau im Spiegel der Erinnerung: GeschichteBestände - Forschungsstätte, Sigmaringen 1997.

${ }^{28}$ J. Fercz, Die Alt- und Sonderbestände der Universitätsbibliothek in Breslau, w: 26. ABDOS-Tagung - Prag, 5. bis 8. Mai 1997, Referate und Beiträge, red. W. Andreesen, Berlin 1997, s. 184-195.

${ }^{29}$ E. Głodowska, A. Ładomirski, Die bedeutensten schlesischen Bibliotheken und Archive: Bestände und Möglichkeiten ihrer Nutzung, w: 24. ABDOS-Tagung, Leipzig, 22. bis 25. Mai 1995, Referate und Beiträge, red. W. Andreesen, Berlin 1995, s. 22-33.

${ }^{30}$ Z. Żmigrodzki, Bibliotheken der katholischen Kirche im oberschlesischen Raum und ihre Rolle in der Gestaltung demokratischer Lesekultur, w: ABDOS-Tagung - Kiel, 13. bis 16. Mai 1996, Referate und Beiträge, red. W. Andreesen, Berlin 1996, s. 168-169; idem, Automatisierte Informationsdienste der Hochschulbibliotheken in Kattowitz und Oppeln, w: 26. ABDOS-Tagung - Prag, 5. bis 8. Mai 1997, Referate und Beiträge, red. W. Andreesen, Berlin 1997, s. 156-157; Z. Gębolyś, Das deutsche Buch und die deutsche Presse im Lesesaal der Stadtbibliothek Kattowitz, w: 26. ABDOS-Tagung-Prag, 5. bis 8. Mai 1997, Referate und Beiträge, red. W. Andreesen, Berlin 1997, s. 200-201; idem, D. Sieradzka, Schlesienkundliche Arbeiten im Institut für Bibliothekswissenschaft und wissenschaftliche Information an der schlesischen Universität, w: 28. ABDOS-Tagung - Zagreb, 10. bis 13. Mai 1999, Referate und Beiträge, red. W. Andreesen, Berlin 1999, s. 134-152; Z. Żmigrodzki, Die Schlesische Bibliothek zu Kattowitz und ihre bibliographische Tätigkeit, w: 28. ABDOS-Tagung - Zagreb, 10. bis 13. Mai 1999, Referate und Beiträge, red. W. Andreesen, Berlin 1999, s. 131-133; Z. Gębołyś, Erwerbung deutscher Zeitschriften in den öffentlichen Bibliotheken der Woiwodschaft Schlesien, w: Regionale Zusammenarbeit in einem vereinten Europa, 31. ABDOS-Tagung - Liberec/Reichenberg, 6. bis 9. Mai 2002, Referate und Beiträge, red. F. Görner, Berlin 2002, s. 125-143.

31 Z. Platkiewicz, Aktuelle Situation und Perspektiven der öffentlichen Bibliotheken in Polen am Beispiel der Region Poznan, „Bibliotheksdienst” 1993, t. 27, nr 3, s. 335-342.

32 A. Jazdon, Die deutschsprachigen Bestände der Universitätsbibliothek und anderer wissenschaftlicher Bibliotheken in Posen/Poznan, "Nordost-Archiv (Neue Fol- 
Pomorskiej w Szczecinie ${ }^{33}$, taki sam informacyjny charakter miał artykuł Zbigniewa Gębołysia o bibliotekach mniejszości niemieckich w Polsce, opublikowany w tomie materiałów pokonferencyjnych w $2001 \mathrm{roku}^{34}$.

Tomy z materiałami po kolejnych konferencjach organizowanych przez ABDOS są bardzo ciekawym źródłem wiedzy o polskich bibliotekach. Najczęściej jednak odzwierciedlają indywidualne pasje i zainteresowania referentów ${ }^{35}$. Problemy bardzo szczegółowe ${ }^{36}$ przeplatają się z próbami szerszych ujęć, gdy autorzy charakteryzują biblioteki konkretnych regionów ${ }^{37}$.

ge)" 1995, t. 4, nr 1 (Das deutsche Buch in Ostmitteleuropa. Bestände und Rezeption), s. $101-116$.

${ }^{33}$ W. Michnal, Die Pommersche Landesbibliothek in Szczecin/Stettin. Eine Bibliothek, die für alle Ideen und Initiativen offen ist, „Bibliotheksdienst” 1998, t. 32, nr 5, s. 852-857. W publikacjach pokonferencyjnych ABDOS por. W. Nieznanowska, Die Stettiner wissenschaftlichen Bibliotheken, w: 20. ABDOSD-Tagung - Köln, 30. April-3. Mai 1991, Referate und Beiträge, red. M. Batisweiler, Berlin 1991, s. 136-141.

${ }^{34}$ Z. Gębołyś, Die Bibliotheken der deutschen Minderheit im heutigen Polen, w: Internationale Zusammenarbeit im neuen Jahrtausend, Thorn, 4.-7. Juni 2001, Berlin 2001, s. $104-119$.

${ }^{35} \mathrm{H}$. Laskarzewska, "Guide to historical book collections of Polish origin and founded on Polish lands until 1950" - documentation and editorial work, w: 27. ABDOS-Tagung Göttingen, 18. bis 21. Mai 1998, Referate und Beiträge, red. W. Andreesen, Berlin 1998, s. 61-64; Z. Gębołyś, Zum Stand der slawistischen Sammlungen in Polen, w: Slawistik, Baltistik und Balkanologie in einem neuen Europa, 29. ABDOS-Tagung - Berlin, 29. Mai bis 1. Juni 2000, Referate und Beiträge, red. F. Görner, Berlin 2000, s. 231-247; J. Krajewski, The aims and assignment of Association of Polish Libraries, w: Slawistik, Baltistik und Balkanologie in einem neuen Europa, 29. ABDOS-Tagung - Berlin, 29. Mai bis 1. Juni 2000, Referate und Beiträge, red. F. Görner, Berlin 2000, s. 184-185; M. Adamiec, Polish Literature on the Internet, w: Die erweiterte Europäische Union und Südosteuropa. Stand und Perspektiven der Informationsvermittlung, 33. ABDOS-Tagung, Kiel, 24. bis 26. Mai 2004, red. F. Görner, Berlin 2005, s. 59-67.

${ }^{36}$ Z. Żmigrodzki, Die ideologisch-politische Zensur in polnischen Bibliotheken 1945-2000, w: Slawistik, Baltistik und Balkanologie in einem neuen Europa, 29. ABDOS-Tagung - Berlin, 29. Mai bis 1. Juni 2000, Referate und Beiträge, red. F. Görner, Berlin 2000, s. 282-286; idem, Political correctness and bias - eine Bedrohung der Lese- und Informationsfreiheit, w: Dienstleiter Bibliothek - Partner für Wissenschaft, Wirtschaft und Politik, 34. ABDOS-Tagung, Bern, 23. bis 25. Mai 2005, Referate und Beiträge, red. F. Görner, Berlin 2005, s. 107-108.

${ }^{37}$ I. Motowilczuk, Die Bibliothek des Deutschen Historischen Instituts Warschau. Kurzbericht, "ABDOS-Mitteilungen” 1997, t. 17, nr 3-4, s. 11-12; S. Wiederkehr, Die Bibliothek des Deutschen Historischen Instituts Warschau in der polnischen Bibliothekslandschaft, w: Die Osteuropabibliothek der Zukunft. Das Bibliotheks- und Informationswesen zu Osteuropa vor neuen Herausforderungen, 37. ABDOS-Tagung, Marburg, 26. bis 28. Mai 2008, Referate und Beiträge, red. F. Görner, Berlin 2008, s. 62-68; S. Kamiński, Die 
Niektóre biblioteki niemieckie zajmują się przede wszystkim problematyką polskich Ziem Zachodnich, tj. - jeśliby patrzeć z perspektywy niemieckiej - ziemiami pruskich prowincji wschodnich lub wschodnich kresów Rzeszy Niemieckiej. Gromadzą książki i wszelkie inne materiały na ten temat. Dwukrotnie miałem przyjemność charakteryzować zasoby tych bibliotek ${ }^{38}$.

Dyrektor Bawarskiej Biblioteki Państwowej Franz Kaltwasser przedstawił rezultaty realizowanego pod koniec lat 90. wielkiego projektu, finansowanego przez Fundację Roberta Boscha. Zgodnie z założeniami zmikrofilmowano kilka tysięcy książek znajdujących się $\mathrm{w}$ polskich bibliotekach, które dokumentują kulturową i polityczną obecność Niemców w Europie Wschodniej3.

W roku 1995 wydano rozprawę Stan wspótpracy z bibliotekami w Europie Środkowej $i$ Wschodniej, gdzie mowa również o Polsce ${ }^{40}$. W pracy dyplomowej o różnych formach kooperacji bibliotek w latach 1980-1999

Universitätsbibliothek in Warschau. Geschichte und historische Sammlungen, w: 14. ABDOSD-Tagung - Lüneburg, 13.-15. Mai 1985, Referate und Beiträge, red. M. Novák, Berlin 1985, s. 57-75; idem, Der Austausch von Publikationen zwischen der UB Warschau und Bibliotheken sowie kulturellen Institutionen in der Bundesrepublik Deutschland und in West Berlin, w: 15. ABDOSD-Tagung - Würzburg, 5.-7. Mai 1986, Referate und Beiträge, red. M. Novák, Berlin 1986, s. 65-71; H. Laskarzewska, Baltica at the [Polish] National Library. A communique, w: 23. ABDOS-Tagung - Tallinn, 9. bis 12. Mai, 1994, Referate und Beiträge, red. W. Andreesen, Berlin 1994, s. 71-73; W. Neznanowska, Stanistaw Konopka-Hauptbibliothek für Medizin in Warschau, w: ABDOS-Tagung, Kiel, 13. bis 16. Mai 1996, Referate und Beiträge, red. W. Andreesen, Berlin 1996, s. 129-131.

${ }^{38}$ W. Kessler, Księgozbiory śląskie w niemieckich bibliotekach, "Studia Śląskie” 2003, t. 62, s. 108-120; idem, Bibliotheken zur deutschen Geschichte und Kultur im östlichen Europa, „ABDOS-Mitteilungen” 2010, t. 30, nr 1, s. 1-21.

${ }^{39}$ F.G. Kaltwasser, H. Weber, In Büchern manifestiert sich der geistige Austausch zwischen Polen und Deutschland: Bericht über ein deutsch-polnisches Gemeinschaftsprojekt, „Zeitschrift für Bibliothekswesen und Bibliographie” 2003, t. 50, nr 2, s. 78-88; Por. H. Gonschior, Zusammenarbeit der Bayerischen Staatsbibliothek mit polnischen Bibliotheken. Das Projekt "Verbesserung der Zugänglichkeit und des Schutzes von Druckwerken im Schnittfeld polnischer und deutscher Kultur in polnischen Bibliotheken: Ein gemeinsames europäisches Erbe, w: Internationale Zusammenarbeit im neuen Jahrtausend..., s. 33-35; Europäisches Kulturerbe bewahren. Verfilmung von Druckwerken im Schnittfeld polnischer und deutscher Kultur = Ochrona wspólnego dziedzictwa europejskiego. Mikrofilmowanie zabytków piśmiennictwa z polsko-niemieckiego pogranicza kulturowego, red. M. Pflüger, Stuttgart 2002. O drugim polsko-niemieckim projekcie por. E. Simon, Informationsversorgung und Netzbildung. Strategische Überlegungen - am Beispiel eines deutsch-polnischen Projekts, w: 26. ABDOS-Tagung - Prag, 5. bis 8. Mai 1997, Referate und Beiträge, red. W. Andreesen, Berlin 1997, s. 81-84.

40 Zusammenarbeit mit Bibliotheken in Mittel- und Ostmitteleuropa. Eine Bestandsaufnahme, red. B. Schleihagen, Berlin 1995. 
Rainer Stanke twierdził, że owa współpraca wygląda nieźle, gdy jest realizowana na podstawie umów partnerskich między poszczególnymi uniwersytetami oraz ich bibliotekami. Brakuje jednak precyzyjnie opracowanych programów tej kooperacji i nie jest ona systematyczna ${ }^{41}$.

Na przykłady dobrej współpracy międzybibliotecznej w euroregionach wskazują Gabriela Ullrich i Ursula Bertz ${ }^{42}$, a o bieżącej działalności bibliotek we Frankfurcie nad Odrą i w Słubicach informują komunikaty zamieszczane $\mathrm{w}$ pokonferencyjnych tomach ogłaszanych przez ABDOS za lata 2001 i $2004^{43}$.

Zdynamizowaniu owej współpracy służyć mogą robocze kontakty między poszczególnymi bibliotekami. Szkoda, że nie zawsze animatorzy tego rodzaju współdziałania dbają o to, by pozostawić dokumentujące te wydarzenia ślady swych działań. Na przykład zorganizowany przez Horsta von Chmielewskiego w roku 1988 wyjazd 20 niemieckich bibliotekarek i bibliotekarzy do Polski nie został odnotowany w niemieckich czasopismach bibliotekarskich. Zadbano natomiast, by opisać podróż grupy roboczej bibliotekarek, odbytą w roku $2001^{44}$, i wyjazd studyjny polskich bibliotekarzy do Saksonii i Turyngii ${ }^{45}$.

Znajdziemy poza tym rozmaite doniesienia w internecie. Jeśli chodzi o biblioteki polskie, to niemiecki użytkownik Wikipedii odnajdzie

${ }^{41}$ R. Stanke, Zusammenarbeit deutscher wissenschaftlicher Bibliotheken mit Bibliotheken in Polen seit 1980. Diplomarbeit. Fachhochschule Stuttgart, Stuttgart 1999, http:// opus.bsz-bw.de/hdms/volltexte/2003/269/ [dostęp: 30.11.2013].

${ }^{42}$ G. Ullrich, U. Bertz, MOE-Projekt erfolgreich beendet. Die Zusammenarbeit der Partnerbibliotheken wird fortgesetzt, "Bibliotheksdienst” 2000, t. 34, nr 2, s. 219; por. pracę dyplomową B. Gerlach, Deutschland und seine Nachbarn: Fallstudien zur grenzüberschreitenden Bibliotheksarbeit. Diplomarbeit. Fachhochschule Stuttgart 2000, http://opus.bszbw.de/hdms/volltexte/2003/168/ [dostęp: 30.11.2013].

${ }^{43}$ G. Twardak, Deutsch-polnische Bibliothekskooperation zwischen der Bibliothek des Collegium Polonicum in Stubice und der Bibliothek der Viadrina in Frankfurt-Oder als Beispiel europaischer Integration, w: Internationale Zusammenarbeit im neuen Jahrtausend..., s. 36; C. Kwiatek-Mack, Das Deutsch-Polnische Dokumentations- und Medienzentrum am Europäischen Wissenschaftszentrum in Stubice und Frankfurt (Oder), w: Die erweiterte Europäische Union und Südosteuropa..., s. 133-136; M. Hager, Das Karl Dedecius Archiv an der Europa-Universität Viadrina im Collegium Polonicum in Stubice, "ABDOS-Mitteilungen" 2003, t. 23, nr 3-4, s. 12-15.

${ }^{44}$ Bibliotheksreise nach Warschau und Krakau. Aktuelle Ansichten und Gespräche zur deutsch-polnischen Geschichte. [Akribie, Arbeitskreis kritischer Bibliothekarinnen], Nümbrecht 2002 (wyd. 2, popr. 2003).

${ }^{45}$ Goethe-Institut Warschau, Bibliotheken in Sachsen und Thüringen - europäische Multimediazentren: Studienfahrt polnischer Bibliothekare, Warschau 2010, http://www. goethe.de/ins/pl/lp/kul/dup/bib/de6320427.htm [dostęp: 30.11.2013]. 
linki do 14 najważniejszych bibliotek polskich. W opracowaniu poszczególnych haseł autorzy opierali się przede wszystkim na Przewodniku po niemieckich ksieggozbiorach historycznych. Na stronie internetowej Niemieckiego Związku Bibliotecznego znaleźć można linki do pełnych tekstów artykułów, które ukazały się w ostatnich latach, m.in. do napisanego w języku angielskim tekstu Andrzeja Mężyńskiego, poświęconego bibliotekom naukowym w Polsce ${ }^{46}$. Warto też wspomnieć o internetowych publikacjach warszawskiego Instytutu Goethego na temat Biblioteki Narodowej, bibliotek publicznych i programów wspierania bibliotek ${ }^{47}$. „Polonica non leguntur" jest najwyraźniej dalej aktualne. Najogólniej można powiedzieć, że w internecie polskie biblioteki nie są ani lepiej, ani gorzej postrzegane niż biblioteki innych państw Europy Środkowo-Wschodniej ${ }^{48}$. Godny uwagi jest, omawiany na przywołanej stronie Niemieckiego Związku Bibliotecznego, realizowany od 2011 roku, projekt studencki pod nazwą „Leksykon państw”. Projektem tym kieruje Gerhard Hacker, a pośród wielu haseł znaleźć możemy „Landerlexikon - Polen”. Być może właśnie na stronie tego projektu można stworzyć solidną internetową encyklopedię bibliotekarstwa polskiego ${ }^{49}$.

Dzieje polskiej książki i bibliotek, zwłaszcza we wczesnych latach nowożytnych - mówiąc najogólniej - są całkiem przyzwoicie pokazane. $\mathrm{W}$ podstawowej dla tej dziedziny pracy Lexikon des gesamten Buchwesens znajdziemy solidnie opracowane informacje na ten temat ${ }^{50}$.

${ }^{46}$ A. Mężyński, Research Libraries in Poland in search of identity, "The Library Review" (Przegląd Biblioteczny), Special Issue, 2012, http://www.sbp.pl/library_review/ full_text/?cid=6190 [dostęp: 30.11.2013].

47 T. Makowski, Die Polnische Nationalbibliothek zu Beginn des 21. Jahrhunderts - zwischen Umorganisation, Archivierung und baulicher Modernisierung bis zur Digitalen Nationalbibliothek POLONA (2012), http://www.goethe.de/ins/pl/lp/kul/dup/bib/de9039149. htm; E. Stefańczyk, Jeder fünfte Pole nutzt öffentliche Bibliotheken - Über die aktuelle Situation und Zukunft der polnischen Bibliotheken (2011), http://www.goethe.de/ins/pl/lp/ kul/dup/bib/de8214804.htm; P. Kieżun, Förderprogramme für polnische Bibliotheken: Programme der Regierung und der Nichtregierungsorganisationen (2010), http://www.goethe. de/ins/pl/lp/kul/dup/bib/de6447205.htm; B. Budyńska, Öffentliche Bibliotheken in Polen: Öffentliche Bibliotheken in Polen erfüllen viele Funktionen, werden von rund einem Fünftel der Bevölkerung genutzt - aber sie haben zu wenig Räume (2010), http://www.goethe.de/ ins/pl/lp/kul/dup/bib/de6316106.htm [dostęp: 30.11.2013].

${ }^{48}$ W. Kessler, Das Bibliothekswesen in Ost-, Ostmittel- und Südosteuropa als Thema deutscher Zeitschriften für Bibliotheken und Bibliothekar(inn)e(n), „Bibliothek und Medien” 2013, t. 2 [oddany do druku].

49 Zob. www.bibliotheksportal.de.

${ }^{50}$ Lexikon des gesamten Buchwesens, t. 1-8, Stuttgart 1987-2014. 
Prezentacja współczesnych badań księgoznawczych w Polsce w niemieckojęzycznych wydawnictwach wymagałaby odrębnego artykułu ze względu na pokaźną liczbę opracowań. Spośród autorów publikujących w wydawnictwach "Gutenberg-Jahrbuch” i „Wolfenbütteler Nachrichten zur Buchgeschichte" wymienię jedynie Jana Pirożyńskiego i niemieckich germanistów: Klausa Garbera ${ }^{51}$ i Detlefa Haberlanda ${ }^{52}$. Ci ostatni zajmują się dziejami bibliotek oraz proweniencją księgozbiorów zrabowanych w czasie wojny przez nazistów. Wyraźnie badania te nasiliły się po publikacjach Andrzeja Mężyńskiego ${ }^{53}$, przy czym w latach 80. dotyczyły one przede wszystkim dziejów książki w Generalnym Gubernatorstwie ${ }^{54}$.

Dla niemieckich germanistów szczególnie interesujące są historyczne księgozbiory niemieckie w Europie Środkowo-Wschodniej. Klaus Garber w rozprawie Handbuch des personalen Gelegenheitsschrifttums in europäischen Bibliotheken und Archiven ${ }^{55}$ pisze sporo o bibliotekach polskich i ich zasobach. Dzieje książki, bibliologia i polskie książki w niemieckich bibliotekach to tematy na odrębne opracowanie ${ }^{56}$. Z żalem należy

${ }^{51}$ K. Garber, Das alte Buch im alten Europa. Auf Spurensuche in den Schatzhäusern des alten Kontinents, München 2006.

${ }^{52}$ D. Haberland, Kommentierte Bibliographie zum Buch-und Bibliothekswesen in Schlesien bis 1800, München 2010.

53 A. Mężyński, Polnische Bibliotheken in den Jahren 1939 bis 1945. Die Politik der Besatzungsmächte und der Verlust von Büchersammlungen in Polen, w: Bibliotheken in der NS-Zeit. Provenienzforschung und Bibliotheksgeschichte, red. S. Alker, Ch. Köstner, Göttingen 2008, s. 291-301; D. Zimmer, Gestempelte Bücher. Ein mutmaßlicher Raubgut-Bestand in der Bibliothek des Herder-Instituts in Marburg, „Bibliothek. Forschung und Praxis" 2009, t. 33, nr 1, s. 88-92.

${ }^{54}$ J. Pirożyński, K. Bednarska-Ruszajowa, Die nationalsozalistsische Bibliothekspolitik in Polen während des Zweiten Weltkriegs, w: Bibliotheken während des Nationalsozialismus, red. P. Vodosek, Wiesbaden 1989, s. 199-232; S. Arend, "Die Faszination des Möglichen". Die Beteiligung von Prof. Dr. Dagobert Frey (Universität Breslau) und Prof. Dr. Otto Kletzl (Reichsuniversität Posen) am NS-Kulturraub im besetzten Polen in der Zeit des Zweiten Weltkriegs, w: NS-Raubgut in Museen, Bibliotheken und Archiven, red. R. Dehmel, Frankfurt am Main 2012, s. 217-230; N. Cieślińska-Lobkowicz, Wer, was, woher, wohin. Geographie des NS-Kunstraubs in Polen und verschiedene Ausfuhrwege der konfinszierten Kulturgüter, NS-Raubgut in Museen, Bibliotheken und Archiven, red. R. Dehmel, Frankfurt am Main 2012, s. 175-192.

${ }^{55}$ Handbuch des personalen Gelegenheitsschriftums in europäischen Bibliotheken und Archiven, red. K. Garber, t. 1-37, Hildesheim 2001-2013.

56 V. Neumann, Polonica in der Staatsbibliothek Berlin, w: "Integration durch Information - We love to inform you...", w: 38. ABDOS-Tagung, Martin, Slowakei, 18. bis 21. Mai 2009, Referate und Beiträge, red. F. Görner, Berlin 2010, s. 77-79; por. ogólnie Handbuch der historischen Buchbestände in Deutschland, t. 1-27, Hildesheim 1996-2000. 
stwierdzić, że wydana w 1994 roku bibliografia Krystyny Ruszajowej nie zainicjowała nowych prac bibliotekoznawczych dotyczących Polski ${ }^{57}$.

Warto pamiętać, że jakość wiedzy o polskim bibliotekarstwie zależy od polskich autorów, którzy publikują w języku niemieckim lub angielskim. Ogólne i syntetyczne dane o Polsce, jak „Landerberichte” - raporty o Polsce z lat 1976, 1991 i 2009, nie zawierają żadnych wiadomości o bibliotekach ${ }^{58}$.

Tak czy inaczej, różne informacje o polskich bibliotekach zaczęły pojawiać się $\mathrm{w}$ fachowym czasopiśmiennictwie niemieckim około roku 1980, ale są dość przypadkowe i raczej sporadyczne. Autorami są niemal wyłącznie Polacy, którzy utrzymują kontakty z niemieckimi bibliotekami i bibliotekarzami. Te relacje to efekt pracy m.in. Bibliotekarskiego Stanowiska ds. Kontaktów Zagranicznych, którym kierowała Elisabeth Simon $^{59}$. Placówka ta musiała jednak zakończyć działalność w roku 2000, gdy rozwiązano Niemiecki Instytut Biblioteczny, który - jak dotychczas nie znalazł kontynuatorów ${ }^{60}$. Razem $\mathrm{z}$ instytutem zakończyło swoją pracę, firmowane przezeń, stanowisko. W rezultacie brak dziś w Niemczech instytucji zainteresowanej systematycznymi kontaktami z bibliotekami zagranicznymi. Pozostają jedynie osobiste inicjatywy i organizowane co dwa lata przez Bibliotekę im. Martina Opitza w Herne międzynarodowe konferencje, w których bibliotekarze polscy biorą bardziej znaczący udział tylko wtedy, gdy odbywają się one w Polsce.

Od połowy ostatniego dziesięciolecia próżno szukać w niemieckich czasopismach bibliotekarskich artykułów na temat aktualnych zagadnień dotyczących bibliotek w Polsce, a przyczynki historyczne nie pojawiają się $\mathrm{w}$ periodykach poświęconych dziejom książki. Złożyło się na to wiele czynników: skupienie wysiłków na różnego rodzaju bibliotekach cyfrowych, zmniejszenie zasobów wschodnioeuropejskich w bibliotekach naukowych, dający się zaobserwować kryzys tzw. małych kierunków kształcenia (w tym bibliologii) na niemieckich uniwersytetach oraz przyznanie uprzywilejowanej pozycji Bibliotece Państwowej w Berlinie i Bawarskiej Bibliotece Państwowej w Monachium. Jeśli chodzi o Polskę, wyjątkową pozycję zajmują Biblioteka Instytutu im. Herdera w Marburgu

${ }^{57}$ K. Bednarska-Ruszajowa, Das polnische Buchwesen. Bibliographische Einführung, Frankfurt am Main 1994, s. 239-417: Bibliothekswissenschaft.

${ }^{58}$ Polen, wyd. Johann Gottfried Herder-Institut Marburg...; Länderbericht Polen, red. W. Wöhlke, Bonn 1991; Länderbericht Polen: Geschichte, Politik, Wirtschaft, Gesellschaft, Kultur, red. D. Bingen, K. Ruchniewicz, Frankfurt am Main 2009.

${ }_{59}$ Bibliothekarische Auslandsstelle. Aufgaben, Programme, Ziele, Berlin 1994.

${ }^{60}$ E. Simon, G. Seydelmann, Austausch - Teilhabe - Erfahrung. Bibliothekarische Auslandsarbeit in den Jahren 1963-2000, [Berlin] 2001. 
i Biblioteka im. Martina Opitza w Herne, które zapewniają zaopatrzenie w odpowiednią literaturę.

Nie należy oczekiwać szybkich i korzystniejszych zmian w tym zakresie. Nie sprzyjają temu tendencje rozwojowe współczesnego bibliotekarstwa, w którym coraz mniej zrozumienia znajduje realizacja indywidualnych pasji. Główny nacisk kładzie się na zagadnienia techniczne, powstaje coraz mniej prac dyplomowych dotyczących zawartości zbiorów ${ }^{61}$. W czasach, gdy o znaczeniu biblioteki decyduje przede wszystkim liczba wypożyczeń, gdy jest ona postrzegana wyłącznie przez pryzmat sztywnych schematów tzw. procesu bolońskiego, coraz mniej jest miejsca dla zaangażowania wychodzącego poza wąski zakres pracy. Jeśliby poważnie potraktować myślenie o współczesnej bibliotece jako o swoistym „portalu do przeszłości i przyszłosci" ${ }^{62}$, to byłoby bardzo wiele do zrobienia, szczególnie w kontekście polsko-niemieckim. Myślę tu nie tylko o bliskiej wielu Europejczykom idei digitalizacji księgozbiorów historycznych. Jak długo jednak w Niemczech nie ma centralnej instytucji koordynacyjnej (Niemiecka Biblioteka Narodowa deklaruje się jako biblioteka narodowa, ma jednak $\mathrm{w}$ ramach niemieckiego federalizmu w sferze kultury ograniczone możliwości), będzie trudno wypracować obliczoną na długi okres podstawę współpracy. Skromnie finansowana (5 000000 euro) Niemiecka Biblioteka Cyfrowa ciągle pochłonięta jest rozwiązywaniem problemów technicznych, na inne formy działalności nie ma środków.

W ciągu ćwierćwiecza, w którym kierowałem Martin-Opitz Bibliothek w Herne, bibliotekarstwo zmieniało się bardzo i zmienia w coraz szybszym tempie. Bibliotekarze na nowo muszą określić swą tożsamość. Pisał o tym we wspomnianym już artykule Andrzej Mężyński, a jego ustalenia dotyczą zarówno polskich, jak i niemieckich realiów. Do tego dochodzi nie tylko w Niemczech - wzrastający nacisk ze strony finansujących biblioteki państwowych instytucji, które ciągle żądają, by biblioteki uzasadniały swoje „prawo do istnienia” (właściwie przecież „prawie wszystko można znaleźć w internecie"). To, że postrzeganie zagranicznych kolegów na tym cierpi, że brak czasu na chwilę refleksji nad zasadami własnych działań, przyjmowane jest jako norma - a nie trzeba szczególnie dowodzić, jak bardzo jest to szkodliwe; we wspólnej Europie ciągle można się nauczyć czegoś od innych.

${ }^{61}$ Por. M. von Zmuda-Trzebiatowski, Wie ist Polen und die Literatur im Bestand einer großen deutschen Öffentlichen Bibliothek vertreten. Versuch einer Bestandsuntersuchung am Beispiel der Zentralbücherei der Hamburger Öffentlichen Bücherhallen, Diplomarbeit, Hamburg 1980.

${ }^{62}$ J. Seefeldt, L. Syre, Portale zu Vergangenheit und Zukunft - Bibliotheken in Deutschland, wyd. 2, Hildesheim 2003. 
Polski „pejzaż biblioteczny” jest w niemieckim piśmiennictwie bibliotekarskim zarysowany tak samo jak inne europejskie „pejzaże biblioteczne". Być może nie jest to szczególnie pocieszające, daje jednak okazję do przemyśleń.

Przeł. Bernhard Kwoka

\title{
Polish libraries and problems of contemporary polish librarianship in german professional periodicals
}

\begin{abstract}
Aвstract. Library professional journals in Germany do not have a significant impact on the scientific community within their own areas of interest, though articles published in them reflect quite accurately the most important issues of modern German librarianship.

The range of subjects that appear in all-German professional publications is vast and diversified and covers the following: library architecture and technology, cataloguing, data processing, automation, wide access to comprehensive information, as well as issues related to promoting friendly attitude towards users, presenting all-round packages of services for users, and discuss education and professional training for librarians.

Articles related to problems of modern librarianship from the international perspective, including those related to Polish librarianship, are scarce and marginal. Notwithstanding, publications on the history of books and libraries in Poland, in particular those that relate to early modern era. do get coverage in library periodicals and are published in Germany more often. German specialists are particularly interested in historical German book collections currently held in Central and Eastern Europe.
\end{abstract}

Key words: Germany, library publications, library periodicals, Polish librarianship. 